\title{
CONTRIBUTION OF STREAM DETRIVORES, FUNGI, AND BACTERIA TO LEAF BREAKDOWN BASED ON BIOMASS ESTIMATES
}

\author{
MÄggi Hieber ${ }^{1}$ AND MARK O. Gessner ${ }^{2,3}$ \\ 'Department of Limnology, Swiss Federal Institute for Environmental Science and Technology (EAWAG/ETH), \\ 8600 Dübendorf, Switzerland \\ ${ }^{2}$ Department of Limnology, Swiss Federal Institute for Environmental Science and Technology (EAWAG/ETH), \\ Limnological Research Center, 6047 Kastanienbaum, Switzerland
}

\begin{abstract}
Linking species and ecosystems is currently one of the great challenges in ecology. To this end, we assess here the contributions of bacteria, fungi, and detritivorous invertebrates (shredders) to leaf litter breakdown, a key ecosystem-level process. We enclosed alder (Alnus glutinosa) and willow (Salix fragilis) leaves in coarse-mesh bags (5 g dry mass), placed them in a stream during peak leaf fall, and retrieved them periodically to determine leaf mass remaining and the biomass of leaf-associated organisms. Shredder biomass was derived from numbers and length-mass relationships, bacterial numbers and biomass were determined by epifluorescence microscopy, and fungal biomass was measured as ergosterol. In addition, conidial production of aquatic hyphomycetes was determined. Leaves decomposed rapidly with exponential breakdown coefficients $k$ of $0.035 \mathrm{~d}^{-1}$ (alder) and $0.027 \mathrm{~d}^{-1}$ (willow). Leaves were also quickly colonized within the first $4 \mathrm{wk}$ of decomposition, when shredder biomass reached 263 and $141 \mathrm{mg}$ dry mass/litter bag, respectively. Maximum bacterial numbers (5.6 and $4.8 \times 10^{10} \mathrm{~g}^{-1}$ detrital dry mass) were attained after $8 \mathrm{wk}$ and corresponded to a biomass of 3.6 (alder) and 3.1 (willow) $\mathrm{mg}$ dry mass/g, $<5 \%$ of the maximum fungal biomass ( 77 and $70 \mathrm{mg}$ dry mass/g, respectively). Aquatic hyphomycetes released up to 2.7 and $1.4 \times 10^{6} \mathrm{conidia} \cdot \mathrm{g}^{-1} \cdot \mathrm{d}^{-1}$, equivalent to a daily conidial production of 9.4 and $2.9 \mathrm{mg}$ dry mass/g on alder and willow, respectively. Calculations based on the measured decomposer biomass and conidial production, published microbial growth efficiencies, turnover times, and shredder feeding rates indicate that shredders accounted for the largest portion of overall leaf mass loss $(64 \%$ and $51 \%$ on alder and willow leaves, respectively), fungi contributed at least $15 \%$ and $18 \%$, and bacterial contribution also was estimated to be substantial (7\% and 9\%). Analyses of elemental flows from allochthonous leaf litter thus clearly require a quantitative consideration of the complex decomposer consortium responsible for leaf decomposition.
\end{abstract}

Key words: Alnus glutinosa; Black Forest, Germany; decomposition; fungi; invertebrate shredders; leaf litter; microorganisms; organic matter; Salix fragilis; stream.

\section{INTRODUCTION}

Linking species and ecosystems has been identified as a major challenge to contemporary ecology (e.g., Jones and Lawton 1995, Cardinale et al. 2000). There are many ways to meet this objective. One way consists of assessing the effects of community attributes (e.g., species richness) on ecosystem-level processes, such as primary production, litter decomposition, or nitrogen mineralization and release (Tilman 1999, Hector et al. 2000, Jonsson and Malmqvist 2000, Emmerson et al. 2001). Quantifying the roles of individual species or functional groups in these processes is another approach.

Decomposition of plant litter is a central ecosystem process in a wide range of terrestrial and benthic aquatic systems, including streams, littoral zones of lakes, and coastal marine environments (e.g., Cadisch and

Manuscript received 12 October 2000; revised 23 May 2001; accepted 1 June 2001.

${ }^{3}$ Address correspondence to this author.

E-mail: gessner@eawag.ch
Giller 1997, Gessner et al. 1997, Webster et al. 1999). Headwater streams resemble forest floors in this respect (Wagener et al. 1998), owing to their strong dependence on allochthonous litter inputs from the riparian vegetation (Wallace et al. 1997, Webster and Meyer 1997). However, in contrast to forests, leaf litter in streams forms discrete resource patches (leaf packs), which lack a vertical structure and lend themselves to manipulation. The biotic assemblages associated with these packs are considerably less complex than in soils, and both their fungal and animal components can generally be identified. Decomposition also proceeds much more rapidly in running waters. These features make leaf litter in streams an attractive model system for discerning patterns and mechanisms driving decomposition in natural environments, and for assessing the roles that organisms play in these processes.

Leaf litter breakdown is the result of physical (leaching, abrasion, fragmentation) and biological mineralization and transformation processes, resulting in the generation of $\mathrm{CO}_{2}$ and other inorganic compounds, dis- 
solved (DOM) and fine-particulate organic matter (FPOM), and decomposer biomass (Webster and Benfield 1986, Suberkropp 1998, Gessner et al. 1999). The organisms that drive these processes include detritivorous macroinvertebrates called shredders (Wallace and Webster 1996), bacteria, and filamentous fungi such as aquatic hyphomycetes (Bärlocher 1992, Maltby 1992, Suberkropp 1998). There is evidence that all three groups play a significant role in the litter breakdown process (Anderson and Sedell 1979, Webster and Benfield 1986, Boulton and Boon 1991, Maltby 1992, Suberkropp 1992a, 1998, Gessner et al. 1997, 1999), but the relative importance of shredders, bacteria, and fungi, and the factors controlling possible shifts in dominance are not clear.

The conventional approach to partition the effects of shredders and microorganisms has been to compare the breakdown of leaf litter enclosed in fine mesh bags, which preclude shredder access to leaves, with that of leaves placed in coarse mesh control bags (Boulton and Boon 1991). A limitation of this shredder exclusion technique is the possible unnatural reduction of physical leaf fragmentation and abrasion in fine mesh bags. Furthermore, water circulation patterns may be altered within fine mesh bags, leading to sediment trapping and impeded exchange of dissolved nutrients and oxygen. Shredder exclusion may also affect litter breakdown indirectly by altering the structure of microbial decomposer assemblages (Howe and Suberkropp 1994). Comparing leaf breakdown in insecticide-treated and corresponding reference streams is an elegant alternative to the use of fine and coarse mesh bags (Cuffney et al. 1990). However, for environmental reasons, this approach is only feasible in exceptional cases. A third approach is to estimate the feeding activity of shredders associated with decomposing leaves in the field, based on consumption rates in feeding trials conducted under controlled conditions (Webster 1983).

None of the approaches above is capable of distinguishing between bacteria and fungi involved in the breakdown process. Theoretically, their respective roles may be assessed by measuring respiration rates of decomposing leaves following the addition of selective inhibitors (Padgett 1993). Only a few studies have used this method, however (Kaushik and Hynes 1971, Padgett 1976), probably because it is fraught with potential pitfalls (Oremland and Capone 1988). One possible alternative consists of deducing microbial degradative activity from information on microbial productivity (Baldy et al. 1995, Gessner et al. 1999). The rationale behind this approach is that microbial growth on leaf litter requires assimilation of low molecular mass compounds made available by litter degradation, and that a relatively constant fraction of the assimilated leaf material is used for microbial biomass production.

The present study was set out to depict the decomposition dynamics of leaves in a stream and to elucidate
TABLE 1. Physical and chemical characteristics of the Steina, Black Forest, during the experimental period from October to December 1996.

\begin{tabular}{lccc}
\hline \multicolumn{1}{c}{ Parameter } & $N$ & Mean & Range \\
\hline Watershed area $\left(\mathrm{km}^{2}\right)$ & & 20.5 & \\
Discharge $\left(\mathrm{m}^{3} / \mathrm{s}\right) \dagger$ & & 0.3 & $0.1-2.0$ \\
Water temperature $\left({ }^{\circ} \mathrm{C}\right) \dagger$ & & 4.7 & $0-8.9$ \\
Conductivity $\left(\mu \mathrm{S} / \mathrm{cm}\right.$; at $\left.20^{\circ} \mathrm{C}\right)$ & 10 & 85.6 & $75.2-98.4$ \\
Alkalinity $(\mathrm{mmol} / \mathrm{L})$ & 14 & 0.54 & $0.37-0.64$ \\
$\mathrm{pH}$ & 14 & 6.6 & $6.4-7.1$ \\
$\mathrm{O}_{2}(\mathrm{mg} / \mathrm{L})$ & 4 & 12.1 & $11.4-12.7$ \\
$\mathrm{NH}_{4}-\mathrm{N}(\mu \mathrm{g} / \mathrm{L})$ & 12 & 19.11 & $0.2-61.5$ \\
$\mathrm{NO}_{3}-\mathrm{N}(\mu \mathrm{g} / \mathrm{L})$ & 12 & 677 & $603-757$ \\
$\mathrm{SRP}(\mu \mathrm{g} / \mathrm{L})$ & 12 & 15.8 & $9.3-22.7 \ddagger$ \\
\hline
\end{tabular}

Notes: SRP $=$ soluble reactive phosphorus; $N=$ number of measurements.

$\dagger$ Continuous records.

$\ddagger 183 \mu \mathrm{g} / \mathrm{L}$ on day 28 at the upstream site.

the pattern and magnitude of leaf colonization by macroinvertebrates, bacteria, and fungi. Information on litter-associated decomposer biomass and fungal spore production was then used in conjunction with accounts of shredder feeding rates and microbial growth efficiencies and turnover times to assess the quantitative contribution of the different decomposer groups to overall leaf breakdown.

\section{MATERIAL AND Methods}

\section{Study site}

The study was conducted in a third-order reach of the Steina, a softwater stream located in the southern Black Forest, Germany $\left(8^{\circ} 19^{\prime} \mathrm{E}, 47^{\circ} 48^{\prime} \mathrm{N}\right)$. The Steina drains a catchment underlain mostly with crystalline bedrock. Managed conifer forests dominated by spruce (Picea abies L.) cover $88 \%$ of the catchment. The study reach was located $\sim 10 \mathrm{~km}$ downstream of the source at an elevation of $700 \mathrm{~m}$ above sea level. The channel slope was $1.6 \%$, the width of the channel was 4-6 m, and the average water depth in riffles was $\sim 10 \mathrm{~cm}$ at baseflow. The stream bottom consisted primarily of cobble, pebble, and some boulders. Following a 100yr flood in 1990, the banks and stream bottom of a reach upstream of the study reach were moderately reinforced. A narrow strip of woody riparian vegetation separated the channel from the adjacent meadows of the flood plain. Alder (Alnus glutinosa (L.) Gaertn.) and willow (Salix fragilis L.) were the dominant riparian species, but various other trees and shrubs were also present, together forming a closed canopy along most of the stream length. Table 1 summarizes selected physical and chemical characteristics of the Steina during the study period. Meyer et al. (1990) provide a more detailed account of the stream and its catchment.

\section{Field methods}

Leaf litter of the predominant riparian tree species, alder (A. glutinosa) and willow (S. fragilis), was collected at the study site on 17 October 1996. Leaves 
were picked from the ground just after abscission. Portions of $17.0 \pm 0.2 \mathrm{~g}$ (mean \pm range) for alder and $15.0 \pm 0.2 \mathrm{~g}$ for willow were weighed fresh in the field and placed in nylon mesh bags $(100 \times 55 \times 70 \mathrm{~mm}$ sides; $9-\mathrm{mm}$ effective mesh size) that were supported by a rigid wire construction (Gessner 1991). A total of 140 leaf packs were constructed. Ten randomly chosen packs of each leaf species were set aside and directly returned to the laboratory, where they were dried and weighed to determine initial leaf dry mass. The initial dry mass of alder and willow leaf packs was $5.2 \pm 0.1$ $\mathrm{g}$ (mean $\pm \mathrm{SD}$ ) and $4.5 \pm 0.1 \mathrm{~g}$, respectively. The remaining packs were each tied to a brick and secured in the stream with rebars such that the leaf blades faced the current (Gessner 1991, Gessner et al. 1991). Leaves of both species were each exposed at two sites separated by $700 \mathrm{~m}$. After 1, 3, 7, 14, 28, and $55 \mathrm{~d}$ of submersion, five packs of each leaf species were randomly retrieved at both sites, placed in polyethylene bags half-filled with stream water, and returned to the laboratory in a cool box.

\section{Leaf mass loss}

In the laboratory, leaves were carefully removed from their bags and individually rinsed with filtered lake water to remove adhering debris and invertebrates. The slurry was passed over a $300-\mu \mathrm{m}$ mesh screen and the invertebrates retained by the screen preserved in $70 \%$ ethanol. Two similar discs ( $10 \mathrm{~mm}$ diameter) were cut from each of 10 leaves or leaf pieces from each pack using a cork borer. The first set of 10 discs was preserved in $5 \mathrm{~mL}$ of $2 \%$ formalin and stored at $4^{\circ} \mathrm{C}$ for later determination of bacterial numbers and biomass. The second set was dried to constant mass at $60^{\circ} \mathrm{C}$ before weighing to the nearest $0.1 \mathrm{mg}$. These discs were assumed to have the same mass as those used for bacterial counts. Four willow leaves and three alder leaf halves also were removed to determine sporulation rates of aquatic hyphomycetes. The remaining leaf material was frozen at $-18^{\circ} \mathrm{C}$, later freeze-dried, weighed to the nearest milligram, and ground with a Retsch centrifugal mill (Model ZM1, Retsch GmbH, Haan, Germany) to pass a $0.5-\mathrm{mm}$ mesh screen. Grinding did not result in notable heating of the samples. Subsamples of the ground leaf material $(\sim 100 \mathrm{mg})$ were ashed at $550^{\circ} \mathrm{C}$ to determine ash-free dry mass (AFDM). Total leaf mass remaining (dry mass and AFDM) was then calculated as the sum of the mass of the bulk leaf material, twice the mass of the dried leaf discs, and the mass of the dried leaf pieces used to determine fungal sporulation.

\section{Macroinvertebrates}

The preserved invertebrates were sorted under a dissecting microscope, identified to the lowest possible taxon, counted, and their body lengths measured to the nearest $0.1 \mathrm{~mm}$ using an eyepiece micrometer. Taxa were assigned to functional feeding groups according to various literature sources including Moog (1995) and Merritt and Cummins (1996). Macroinvertebrate biomass was estimated by means of body-length dry-mass relationships, which in most cases had been established with specimens collected in the Steina (Meyer 1989, Burgherr and Meyer 1997, Benke et al. 1999). Because the initial dry mass of alder and willow leaf packs differed, data were normalized to a standard initial mass of $5 \mathrm{~g}$.

\section{Fungi}

Fungal biomass was estimated as ergosterol content (Newell 1992, Gessner and Newell 2002). Analyses were performed following a modification of the procedures described by Gessner and Schmitt (1996). Briefly, ergosterol was extracted from $50 \mathrm{mg}$ of freshly lyophilized and ground leaf material by heating in alkaline methanol $\left(30 \mathrm{~min}, 80^{\circ} \mathrm{C}\right.$, tightly closed screwcap tubes) with stirring. After purification of the extract by solid-phase extraction (SPE) and high-performance liquid chromatography (HPLC), ergosterol was quantified by measuring absorbance at $282 \mathrm{~nm}$. The HPLC column was a LiChrospher-100-RP18 (250 mm length, 4-mm inner diameter, 5- $\mu \mathrm{m}$ particle size, Merck, Dietikon, Switzerland) maintained at $33^{\circ} \mathrm{C}$ with a water jacket that was connected to a water bath. Ergosterol eluted after $8 \mathrm{~min}$. Ergosterol was converted to fungal biomass using a conversion factor of $182 \mathrm{mg}$ fungal dry mass/mg ergosterol (Gessner and Chauvet 1993, Gessner and Newell 2002).

The leaves or leaf pieces retained for determining sporulation rates of aquatic hyphomycetes were placed in $250-\mathrm{mL}$ Erlenmeyer flasks containing $50 \mathrm{~mL}$ of filtered $(0.45-\mu \mathrm{m}$ pore size) stream water and incubated for $42 \mathrm{~h}$ at $10^{\circ} \mathrm{C}$ with gentle shaking. After incubation, the leaf material was removed from the flasks, rinsed, and dried at $60^{\circ} \mathrm{C}(3 \mathrm{~d})$ to determine leaf dry mass. The stream water including the conidia of aquatic hyphomycetes was preserved in formalin ( $2 \%$ final concentration) and stored until analyzed. Species composition and densities of the conidial suspensions were determined at a magnification of $200 \times$ after filtering known volumes over membrane filters $(5-\mu \mathrm{m}$ pore size) and staining the trapped conidia with $0.02 \%$ trypan blue in lactic acid (Gessner et al. 1998). Sporulation rates were converted to conidial production based on conidial dry mass determined for individual species (Bärlocher and Schweizer 1983, Gessner and Chauvet 1994, Chauvet and Suberkropp 1998); in a few species, whose specific conidial mass was unknown, values from species with spores similar in size and shape were used.

\section{Bacteria}

Bacterial numbers and biomass were determined by epifluorescence microscopy after detachment of bacteria from formalin-preserved leaf discs and staining with DAPI (4',6-diamidino-2-phenylindole). Leaf discs were cut 2-3 times with scissors before $5 \mathrm{~mL}$ of filtered 


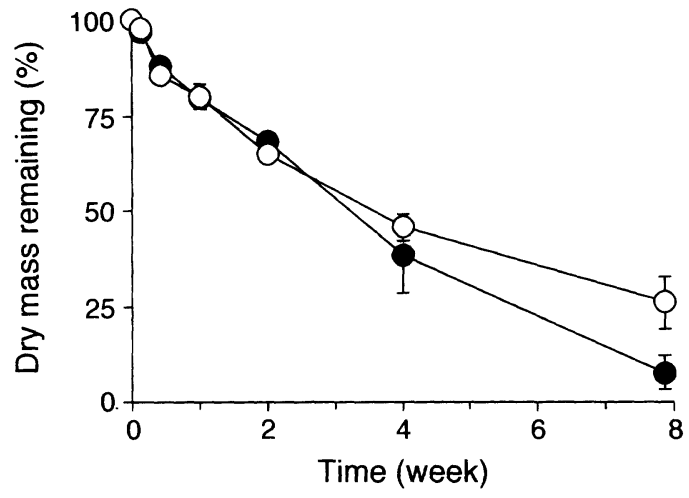

FIG. 1. Dry mass remaining of alder (solid circles) and willow (open circles) leaf packs decomposing in a third-order reach of a Black Forest stream. Error bars indicate $95 \%$ confidence intervals calculated from 10 replicate leaf bags.

(0.2- $\mu \mathrm{m}$ pore size) and autoclaved water was added to samples. The leaf pieces were then homogenized with an Ultra Turrax blender (Janke and Kunkel GmbH and Company KG, Staufen, Germany). A treatment of 3.5 min proved sufficient to obtain homogeneous slurries from alder leaf discs, but $5.5 \mathrm{~min}$ was required for willow leaves. Samples were kept on ice during homogenization. The resulting slurry was passed through a $250-\mu \mathrm{m}$ mesh screen to remove larger leaf pieces. The screen and the retained debris were rinsed four times with $\sim 5 \mathrm{~mL}$ filtered $(0.2-\mu \mathrm{m}$ pore size $)$ and autoclaved water, and the filtrate made up to a final volume of $30 \mathrm{~mL}$. Leaf homogenization and filtration were carried out in a clean bench to minimize post-sampling contamination. Blanks were carried through the whole procedure.

Staining and subsequent microscopy were carried out under red light to minimize loss of fluorescence. A 10$100 \mu \mathrm{L}$ subsample of the bacterial suspension was transferred to a tube and the volume brought to $10 \mathrm{~mL}$ with filtered and autoclaved water. Next, $100 \mu \mathrm{L}$ of a DAPI solution $(0.5 \mathrm{mg} / \mathrm{mL})$ was added (final concentration of $1-5 \mathrm{mg} / \mathrm{L}$ ) and allowed to stain cells for 5 min before the liquid was transferred to a filter funnel and gently sucked through a black polycarbonate filter (0.2- $\mu \mathrm{m}$ pore size, Nuclepore) underlain by a cellulose nitrate backing filter $(0.45 \mu \mathrm{m}$, Sartorius) (Fry 1990).
The bacteria trapped on the filter were counted under a Zeiss Axiolab microscope (filter set no. 02: G 365, FT 395, LP 420, Carl Zeiss AG, Feldbach, Switzerland) at $1000 \times$ magnification. Twenty microscopic fields were viewed per filter, corresponding to a total of about 400 counted cells (Kirchman 1993). The encountered bacteria were assigned to one of several classes defined by color, shape, and size (Table 2 ). The length $(L)$ and width $(W)$ of randomly chosen cells of each class were measured to calculate cell biovolume $(V)$ according to the equation $V=(\pi / 4) \times W^{2} \times(L-W / 3)$ (Bratbak 1993). The average biomass of each class was determined by converting bacterial bioyolume to carbon $(C)$ according to the empirically determined relationship $C$ $=89.6 V^{0.59}$, where $V$ is given in cubic micrometers and $C$ in femtograms (Simon and Azam 1989), and converting bacterial carbon to biomass under the assumption that carbon was $50 \%$ of bacterial dry mass. The resulting carbon densities are intermediate between those derived from the allometric relationship proposed by Theil-Nielsen and Søndergaard (1998) and recent values obtained with a range of other approaches $(\mathrm{Fa}-$ gerbakke et al. 1996, Loferer-Krößbacher et al. 1998, Pelegrí et al. 1999).

\section{Theoretical framework}

The overall biological breakdown of leaves was assumed to be a function ( $g$ ) of shredder ( $\mathrm{s}$ ) feeding, and fungal (f) and bacterial (b) assimilation of litter constituents. In its most general form, this relationship can be written as

$$
\frac{d m}{d t}=-g_{\mathrm{s}}\left(m, B_{\mathrm{s}}\right)-g_{\mathrm{f}}\left(m, B_{\mathrm{f}}\right)-g_{\mathrm{b}}\left(m, B_{\mathrm{b}}\right)
$$

where $m$ is the dry mass of leaf litter, $t$ is the elapsed time after litter input to the system, and $B$ is the biomass of shredders, fungi, and bacteria, respectively. Although this approach makes a number of simplifying assumptions, notably the neglect of trophic and competitive interactions, it is a useful first approximation of the mechanisms operating in nature.

Litter mass loss due to shredder feeding depends on the relative consumption rate (feeding rate per unit body mass) and biomass of shredders present per litter

TABLE 2. Cell dimensions and biomass of major bacterial morphotypes including yellow rodshaped particles (small yellow rods) and cell chains associated with decomposing leaves in a Black Forest stream.

\begin{tabular}{lccccrr}
\hline \multicolumn{1}{c}{ Morphotype } & $\begin{array}{c}\text { Range of } \\
\text { length }(\mu \mathrm{m})\end{array}$ & $\begin{array}{c}\text { Range of } \\
\text { width }(\mu \mathrm{m})\end{array}$ & $\begin{array}{c}\text { Range of } \\
\text { volume } \\
\left(\mu \mathrm{m}_{3}\right)\end{array}$ & $\begin{array}{c}\text { Median } \\
\text { volume } \\
\left(\mu \mathrm{m}_{3}\right)\end{array}$ & $\begin{array}{c}\text { Average Number } \\
\text { biomass } \\
(\mathrm{fg})\end{array}$ & $\begin{array}{c}\text { Numea- } \\
\text { mured }\end{array}$ \\
\hline Cocci & $0.6-1.0$ & $0.6-1.0$ & $0.13-0.52$ & 0.18 & 65 & 9 \\
Small rods & $1.0-2.0$ & $0.5-1.0$ & $0.16-1.70$ & 0.55 & 126 & 285 \\
Small yellow rods & $1.3-2.0$ & $0.5-1.0$ & $0.22-1.54$ & 0.66 & 141 & 48 \\
Large rods & $3.0-4.5$ & $0.5-1.5$ & $0.48-4.86$ & 1.83 & 256 & 69 \\
Thin elongate cells & $3.0-16$ & $0.3-0.7$ & $0.21-5.68$ & 1.49 & 227 & 64 \\
Cell chains & $4.0-11$ & $0.7-1.5$ & $2.15-24.4$ & 8.72 & 643 & 47 \\
\hline
\end{tabular}


bag $\left(\boldsymbol{B}_{\mathrm{s}}\right)$. This relationship can be written as follows:

$$
g_{\mathrm{s}}\left(m, B_{\mathrm{s}}\right)=\varphi \frac{m}{m+c} B_{\mathrm{s}}
$$

where $\varphi$ is the maximum feeding rate (relative consumption rate) and $c$ is a constant that is small compared to the initial leaf mass (e.g., $0.1 \%$ of $m$ ). The term $m /(m+c)$ accounts for the fact that feeding ceases when the leaf mass remaining approaches zero.

Fungal assimilation of leaf constituents is related to the gross growth rate of fungi $\left(\mu_{f}\right)$, the fraction of assimilated leaf material converted to fungal biomass (i.e., fungal growth efficiency, $\varepsilon_{\mathrm{f}}$ ), and the fungal biomass present per litter bag, which in turn is the product of biomass concentration $\left(B_{f}\right.$; milligram fungus per gram leaf material) and the amount of leaf material remaining. Thus,

$$
g_{\mathrm{f}}\left(m, B_{\mathrm{f}}\right)=\left(\frac{\mu_{\mathrm{f}}}{\varepsilon_{\mathrm{f}}}\right) B_{\mathrm{f}} m .
$$

The same basic relationship applies to the bacteria. In the absence of interactions among litter-associated organisms, the overall rate of leaf breakdown is thus given by the equation

$$
\frac{d m}{d t}=-\varphi\left(\frac{m}{m+c}\right) B_{\mathrm{s}}-\left(\frac{\mu_{\mathrm{f}}}{\varepsilon_{\mathrm{f}}}\right) B_{\mathrm{f}} m-\left(\frac{\mu_{\mathrm{b}}}{\varepsilon_{\mathrm{b}}}\right) B_{\mathrm{b}} m .
$$

Physical losses can be expressed in a similar way, but were simply assumed here to be the difference between the total loss of leaf mass and the sum of bacterial, fungal, and shredder-mediated mass losses.

\section{Statistics}

Litter mass loss data were fit to the simple exponential model

$$
m_{t}=m_{0} \times e^{-k t}
$$

where $m_{t}$ is the dry mass remaining at the time $t, m_{0}$ the estimated initial dry mass, and $k$ the breakdown rate coefficient. This model assumes that the mass loss at any given time is directly proportional to the litter mass present. Regressions were calculated using nonlinear iterative fitting procedures.

Two-way analysis of variance (ANOVA) with leaf species and sampling location (upstream vs. downstream site) as factors was initially used to test for differences in the maximum numbers and biomass of total macroinvertebrates, shredders, and bacteria, as well as for fungal biomass and sporulation rates and conidial production of aquatic hyphomycetes. Bacterial and fungal sporulation data were $\ln (x+1)$ transformed before analyses. Because none of the tested parameters showed significant differences between sites, data from the upstream and downstream site were lumped together for further calculations and subsequent comparisons of leaf species using Student's $t$ tests. All sta-
TABLE 3. Summary of breakdown coefficients $(k)$ of alder and willow leaves decomposing in the Steina, Black Forest. as estimated by nonlinear regression analysis.

\begin{tabular}{lcrcc}
\hline Species & $k+\mathrm{CL}\left(\mathrm{d}^{-1}\right)$ & \multicolumn{1}{c}{$m_{0} \pm \mathrm{CL}(\%)$} & $r^{2}$ & $N$ \\
\hline Alder & $-0.0352 \pm 0.0029$ & $100.9 \pm 2.5$ & 0.958 & 70 \\
Willow & $-0.0270 \pm 0.0018$ & $97.5 \pm 1.8$ & 0.964 & 68
\end{tabular}

Notes: $\mathrm{CL}=95 \%$ confidence limit; $m_{0}=$ estimated initial leaf mass; $N=$ number of leaf packs.

tistical analyses were performed with SYSTAT 8.0 (SYSTAT 1998). Differences were considered significant when $P<0.05$.

\section{RESUlts}

\section{Leaf mass loss}

Leaf breakdown of alder and willow leaves was rapid, with $<50 \%$ of leaf dry mass remaining after $4 \mathrm{wk}$ in the stream (Fig. 1). Confidence limits associated with estimated breakdown coefficients indicated that there were significant differences in breakdown rates between leaf species (Table 3), reflecting the fact that alder leaves had lost significantly more $(P<0.001)$ of their initial dry mass after 8 wk $(92 \%)$ than willow leaves (74\%). Leaching during the first $24 \mathrm{~h}$ after placing leaves in the stream was $\leq 3 \%$ (Fig. 1), probably due to the use of fresh leaf litter in this study (Bärlocher 1997, Gessner et al. 1999).

\section{Macroinvertebrates}

Leaf packs were rapidly colonized by macroinvertebrates. Maximum densities were observed $4 \mathrm{wk}$ after leaf submersion, with an average of 708 (alder) and 422 (willow) animals $/ 5$ g leaf pack (Fig. 2A), corresponding to a biomass of 348 (alder) and 209 (willow) $\mathrm{mg} /$ pack (Fig. 2B). Maximum numbers and biomass were significantly higher on alder leaves $(P<0.01)$, but values had converged by 8 wk.

Shredders were the predominant functional feeding group encountered in packs of both leaf species, accounting for an average of $43 \%$ of total invertebrate numbers and $67 \%$ of total biomass (Fig. 2). Eight weeks after leaf submersion, shredders assumed an even greater importance with $>80 \%$ of total macroinvertebrate biomass. As for total macroinvertebrates, significantly higher maximum numbers $(P<0.001)$ and biomass $(P$ $<0.01$ ) occurred on alder leaves on day 28 . The stoneflies Nemoura, Protonemura, Amphinemura, and Leuctra, the caddisfly Potamophylax, and the amphipod Gammarus fossarum were the dominant shredder taxa. Collector-gatherers and scrapers were mainly represented by mayfly larvae such as Baetis and Leptophlebiidae, together accounting for an additional $44 \%$ of total numbers but only $19 \%$ of biomass. Collectorfilterers and predators were a minor component of the macroinvertebrate assemblages. 

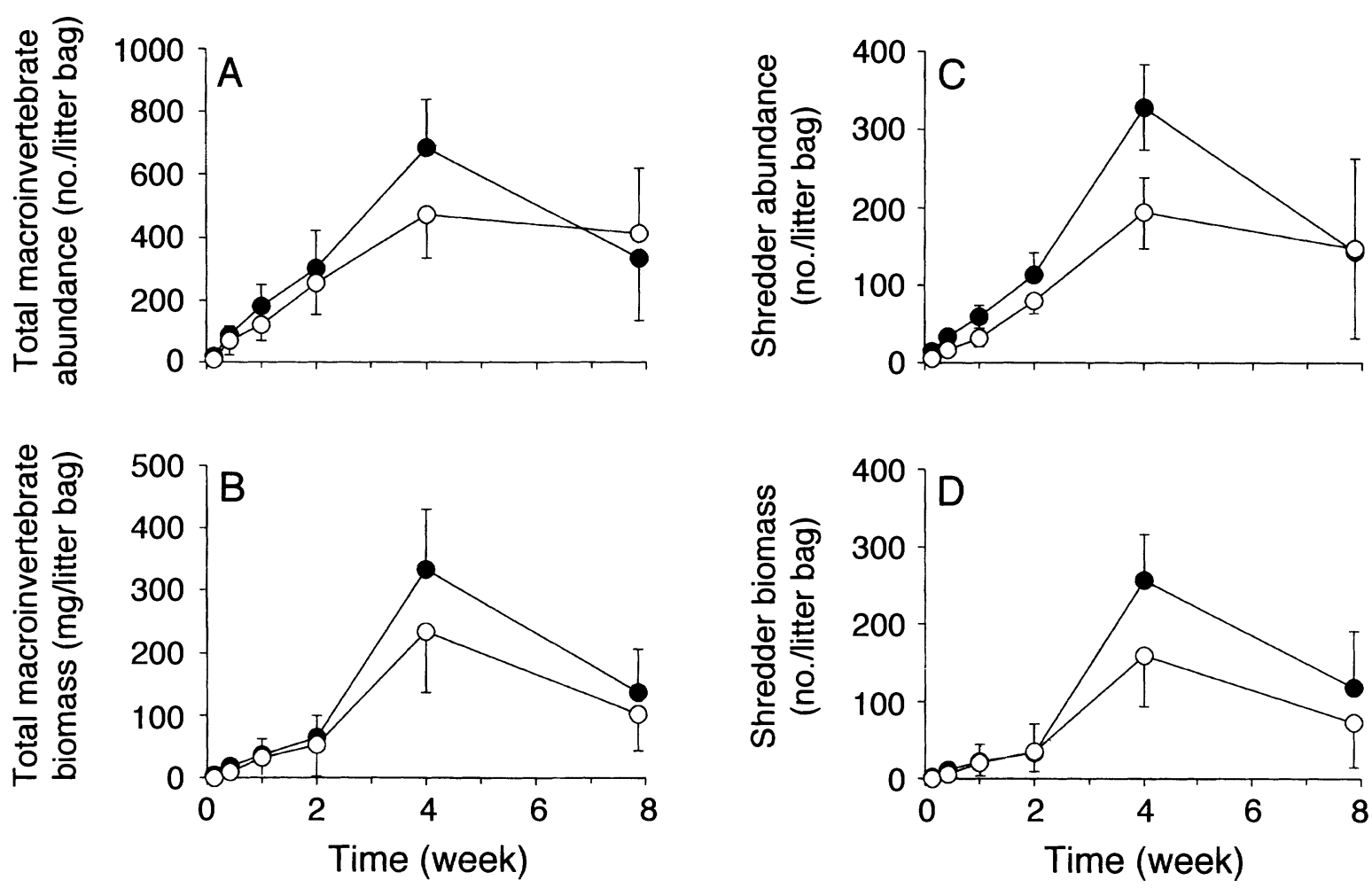

FIG. 2. Numbers (A, B) and biomass (C, D) of total macroinvertebrates (A, C) and shredders (B, D) associated with alder (solid circles) and willow (open circles) leaves decomposing in a third-order reach of a Black Forest stream. Error bars indicate $95 \%$ confidence intervals calculated from 10 replicate leaf bags.

Fungi

Initial fungal biomass $(<20 \mu \mathrm{g}$ ergosterol/g leaf dry mass) indicated that fungal colonization of freshly collected leaves was minor prior to submersion in the stream. During the following $4 \mathrm{wk}$, fungal biomass increased rapidly and then leveled off in both species (Fig. 3A). There were no significant differences in fungal biomass between leaf species.

Sporulation dynamics of aquatic hyphomycetes first paralleled fungal biomass (Fig. 3B). However, in contrast to biomass, sporulation rates dropped on alder leaves $8 \mathrm{wk}$ after leaf exposure. There were significant differences between leaf species in maximum sporulation rates $(P<0.01)$. Because the average size of conidia was larger on alder leaves, the difference between leaf species was even greater when conidial production is expressed in terms of dry mass (Fig. 3C).

A total of 30 species of aquatic hyphomycetes were found to be sporulating on leaves. Flagellospora curvula and Tetrachaetum elegans codominated the assemblage on both types of leaves in terms of conidial numbers, but $T$. elegans greatly outweighed $F$. curvula in terms of conidial mass production (Table 4). Other frequently observed species included one form with elongate rod-shaped conidia (unbranched sp. 1) and one with conidia resembling those of A. longissima but having a significantly greater width (unbranched sp. 2).

\section{Bacteria}

Bacterial numbers and biomass also increased exponentially during the first 4 wk of leaf submersion and remained at about the same level during the following $4 \mathrm{wk}$ (Fig. 4). Maximum bacterial numbers of 4.8 and $5.6 \times 10^{10}$ cells/g detrital dry mass, corresponding to a biomass of 3.1 and $3.6 \mathrm{mg} / \mathrm{g}$ dry mass, were attained after $8 \mathrm{wk}$ on alder and willow leaves, respectively. Values were significantly higher on alder compared to willow leaves for both numbers and biomass $(P<0.05)$. In contrast, when expressed per leaf surface area (data not shown), neither the numbers nor the biomass of bacteria differed significantly between leaf species $(P>0.81)$. Numbers increased from initially $10^{4}$ individuals to a maximum of $3.8 \times 10^{6}$ cells/ $\mathrm{mm}^{2}$, corresponding to a maximum biomass of $0.6 \mu \mathrm{g} /$ $\mathrm{mm}^{2}$.

The bacterial assemblages associated with both alder and willow leaves were dominated by small rods throughout the experiment (Fig. 5) accounting for at least $50 \%$ of the total numbers (average of $74 \%$ ) and biomass (average of 66\%). Cocci occurred regularly in the first $3 \mathrm{~d}$ ( $4 \%$ of total numbers) but subsequently decreased in relative importance, whereas the relative frequencies of thin elongate cells increased with time (range of $1-14 \%$ during the study). The proportion of large rods $(4-11 \%)$ and cell chains $(1-3 \%)$ did not vary 

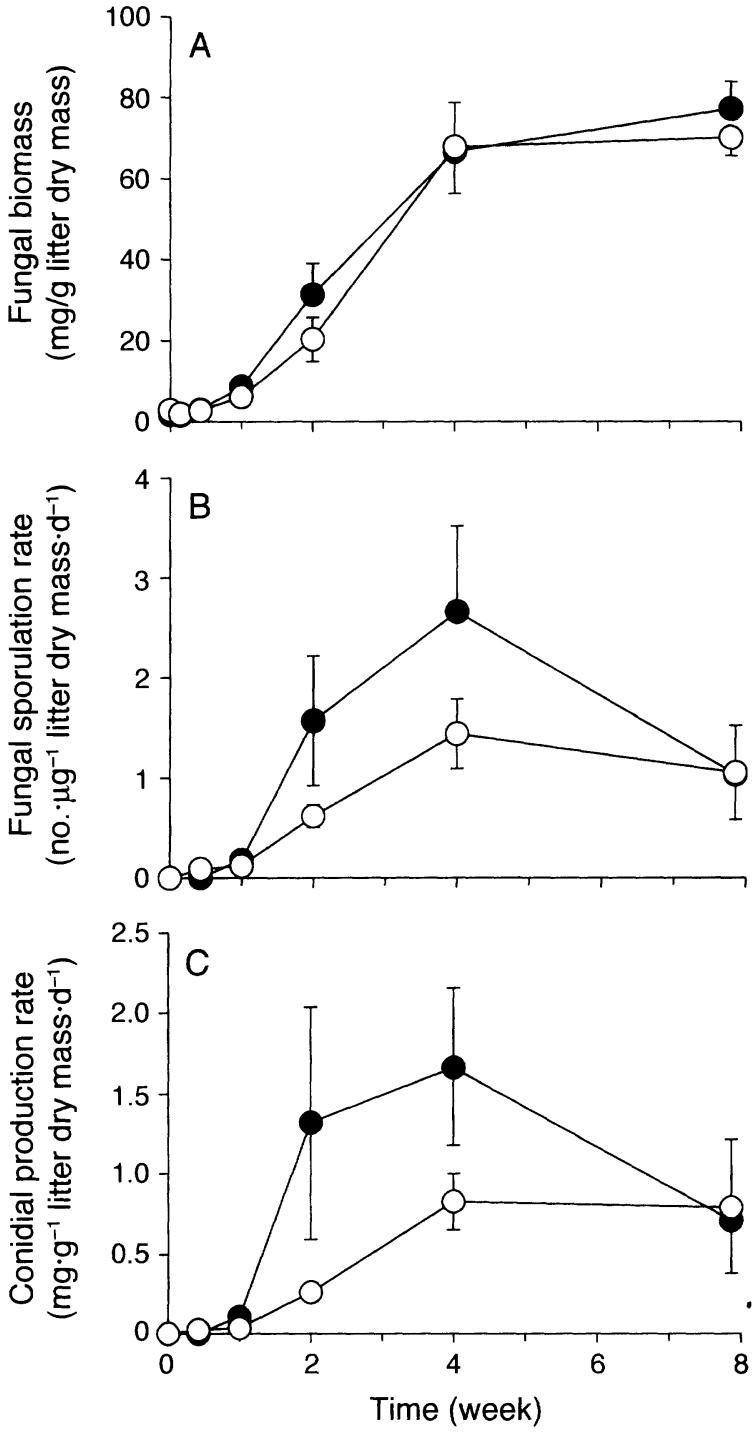

FIG. 3. (A) Biomass, (B) sporulation, and (C) conidial production rates of fungi associated with alder (solid circles) and willow (open circles) leaves decomposing in a third-order reach of a Black Forest stream. Error bars indicate $95 \%$ confidence intervals calculated from 10 replicate leaf bags.

greatly over time. There were no evident differences in the composition of bacterial assemblages on alder and willow leaves. Bright yellow particles closely resembling small rods in size and shape were observed during the first $3 \mathrm{~d}$ of leaf exposure, at this time accounting for $20 \%$ of the total counts. By week 4 , however, the percentage of these particles had decreased to $<2 \%$ of the total counts.

\section{Comparison of assemblages}

All parameters used for the quantitative description of macroinvertebrate, fungal, and bacterial assemblages on decomposing leaves showed strikingly similar temporal patterns, although the relative magnitude of the groups in terms of biomass differed greatly. Bacteria were a consistent but relatively small component of the assemblages, never accounting for $>5 \%$ of the total microbial biomass (i.e., bacterial plus fungal) or $>2 \%$ of the total biomass (also including shredders and other macroinvertebrates) (Fig. 6). The biomass of fungi was greater than that of shredders during early breakdown, particularly on alder leaves, whereas the reverse was true at later stages. Values for all parameters except fungal biomass were consistently higher on alder leaves on one or more sampling dates, whereas significantly higher values were never observed on willow leaves.

\section{DisCUSSION \\ Rapid leaf mass loss as a result of high biological activity}

Breakdown of leaf litter was rapid, as found in a previous experiment conducted in the same stream (Gessner et al. 1991). Although the leaves of alder and some willow species are well known to decompose rapidly (e.g., Petersen and Cummins 1974, Short et al. 1980, Cowan et al. 1983), the rates observed in our study stream range at the higher end of reported values (Webster et al. 1995, Galas et al. 1996, Casas and Gessner 1999).

The rapid breakdown was accompanied by a dense colonization of leaf bags by both microorganisms and macroinvertebrates. The numbers and biomass of macroinvertebrates were either similar to or exceeded values observed on leaves decomposing in other streams with similar characteristics and resident invertebrate assemblages (Short et al. 1980, Cowan et al. 1983, Mutch and Davies 1984, McArthur and Barnes 1988, Gessner and Dobson 1993, Malmqvist and Oberle 1995, Pozo et al. 1998). Bacterial biomass also was on the high end of literature values (e.g., McArthur et al. 1994, Baldy et al. 1995, Weyers and Suberkropp 1996, Maamri et al. 1999), and so was fungal biomass (see compilation in Gessner 1997). Thus, the observed pattern and extent of leaf colonization suggest that much of the leaf breakdown in the present study was due to biological processes. This conclusion is further supported by the dense sporulation of aquatic hyphomycetes, pointing to a high fungal activity in leaves (Gessner 1997), and the clear dominance of shredders in the leaf-associated animal assemblages.

\section{Relative contribution of shredders, bacteria, and fungi to leaf mass loss}

Fungal biomass has been found to account for $63 \%$ to $>99 \%$ of the total microbial biomass (i.e., fungal plus bacterial) associated with decomposing leaves in streams (Findlay and Arsuffi 1989, Baldy et al. 1995, Weyers and Suberkropp 1996, Baldy and Gessner 1997, Gessner 1997). The data of the present study (95-99\%) are in accordance with these previous findings and imply that fungi assume a greater importance in leaf 
TABLE 4. Relative abundance and biomass (\%) of the top 10 aquatic hyphomycete conidia produced on alder and willow leaves decomposing in a Black Forest stream.

\begin{tabular}{|c|c|c|c|c|}
\hline \multirow[b]{2}{*}{ Species } & \multicolumn{2}{|c|}{ Alder } & \multicolumn{2}{|c|}{ Willow } \\
\hline & $\begin{array}{c}\text { Num- } \\
\text { ber }\end{array}$ & $\begin{array}{l}\text { Bio- } \\
\text { mass }\end{array}$ & $\begin{array}{c}\text { Num- } \\
\text { ber }\end{array}$ & $\begin{array}{l}\text { Bio- } \\
\text { mass }\end{array}$ \\
\hline Anguillospora longissima (Sacc. et Syd.) Ingold & 1.6 & 3.3 & 1.7 & 4.3 \\
\hline Clavariopsis aquatica de Wildeman & 5.2 & 5.5 & 4.7 & 6.2 \\
\hline $\begin{array}{l}\text { Clavatospora longibrachiata (Ingold) Marvanová and } \\
\text { S. Nilsson }\end{array}$ & 20.3 & 4.4 & 11.7 & 3.2 \\
\hline Flagellospora curvula Ingold & 28.3 & 8.3 & 32.4 & 11.8 \\
\hline Heliscus lugdunensis Saccardo and Thérry & 3.0 & 1.8 & 10.9 & 8.2 \\
\hline Lemonniera aquatica de Wildeman & 1.8 & 3.1 & 1.4 & 3.0 \\
\hline Lemonniera terrestris Tubaki & 0.9 & 1.3 & 0.5 & 0.8 \\
\hline Tetrachaetum elegans Ingold & 32.0 & 64.8 & 14.1 & 35.3 \\
\hline Unbranched sp. 1 & 1.2 & 3.3 & 3.1 & 10.3 \\
\hline Unbranched sp. 2 & 3.3 & 2.8 & 5.4 & 5.7 \\
\hline Sum & 97.7 & 98.6 & 86.0 & 88.8 \\
\hline
\end{tabular}

breakdown than bacteria. However, although biomass data may provide a first common basis for comparison, they are insufficient for making inferences about relative degradative activities (Gessner 1997). Turnover times of bacteria may be considerably shorter than those of fungi, suggesting that the production and contribution of bacteria to leaf breakdown could be greater than inferred from biomass (Findlay and Arsuffi 1989, Baldy and Gessner 1997). Similarly, the mechanisms of leaf colonization differ strikingly between animals and microorganisms. Microorganisms establish themselves on leaves through growth after initial settling of spores or single cells, whereas the biomass accumulation of macroinvertebrates results primarily from immigration. Consequently, straightforward comparisons of decomposer biomass overrate the contribution of shredders to leaf breakdown and underrate the role of microorganisms, particularly that of bacteria.

Data on decomposer biomass combined with information on microbial growth efficiencies, turnover rates, and feeding activity can provide better insight into the relative importance of different decomposers in leaf breakdown. Published rates of leaf consumption of various shredders that are taxonomically related to the taxa encountered in the present study are remarkably similar. When fed alder, willow, or other types of palatable leaves, nemourid stoneflies (e.g., Short and Ward 1981, Bird and Kaushik 1985), limnephilid caddisflies (e.g., Otto 1974, Arsuffi and Suberkropp 1989), and other insect shredders (e.g., Grafius and Anderson 1979, Herbst 1982, Bird and Kaushik 1985, Arsuffi and Suberkropp 1989) typically consume between $10 \%$ and $80 \%$ of their body mass per day, although some values outside this range have also been reported (e.g., Nolen and Pearson 1993, Hutchens et al. 1997). If, according to Eq. 2, an average consumption rate $(\varphi)$ of $0.4 \mathrm{mg}$ leaf mass $\cdot(\mathrm{mg} \text { body mass })^{-1} \cdot \mathrm{d}^{-1}$ is assumed, shredder feeding would account for a leaf mass loss of $30 \%$ (alder) and $24 \%$ (willow) by day 28 , and $64 \%$ and $51 \%$ by day 55 (Table 5 ). These estimated contributions are high compared to values calculated from literature data on similar shredder assemblages associated with decomposing leaves (Table 6), reflecting the particularly dense colonization in the present study.

A higher shredder biomass has only been observed in a Rocky Mountain stream in Alberta, Canada, at $1750 \mathrm{~m}$ elevation (Mutch and Davies 1984). The impossibly high estimate of the contribution of shredders to litter breakdown $(227 \%)$ calculated in that case (Table 6) can be explained by the overestimation of feeding rates at the freezing temperatures prevailing in that stream. If, therefore, a feeding rate at the low end of
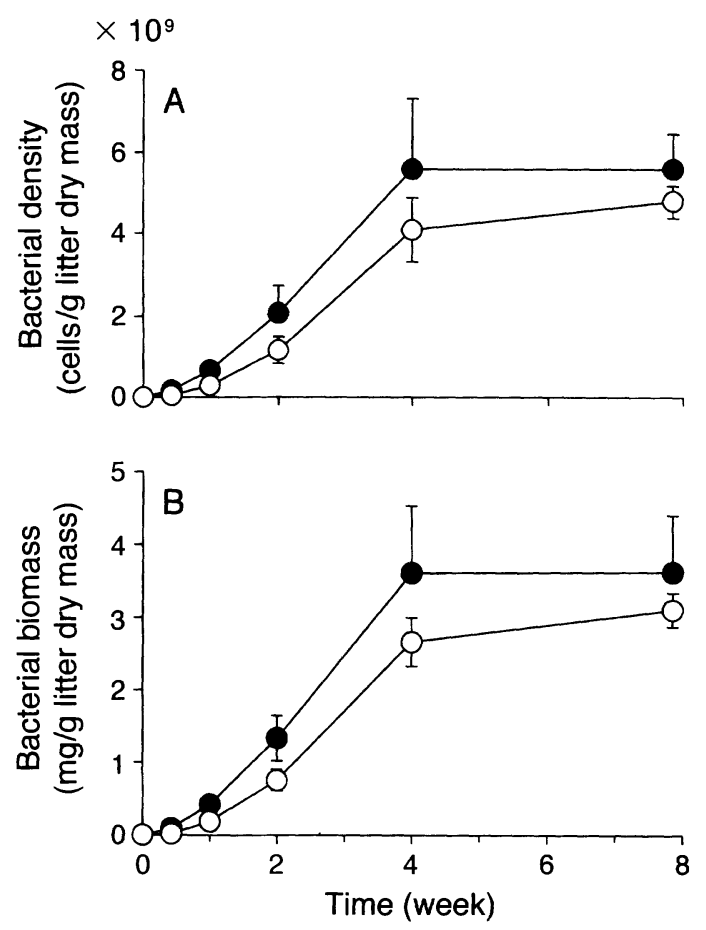

FIG. 4. (A) Numbers and (B) biomass of bacteria associated with alder (solid circles) and willow (open circles) leaves decomposing in a third-order reach of a Black Forest stream. Error bars indicate $95 \%$ confidence intervals calculated from 10 replicate leaf bags. 

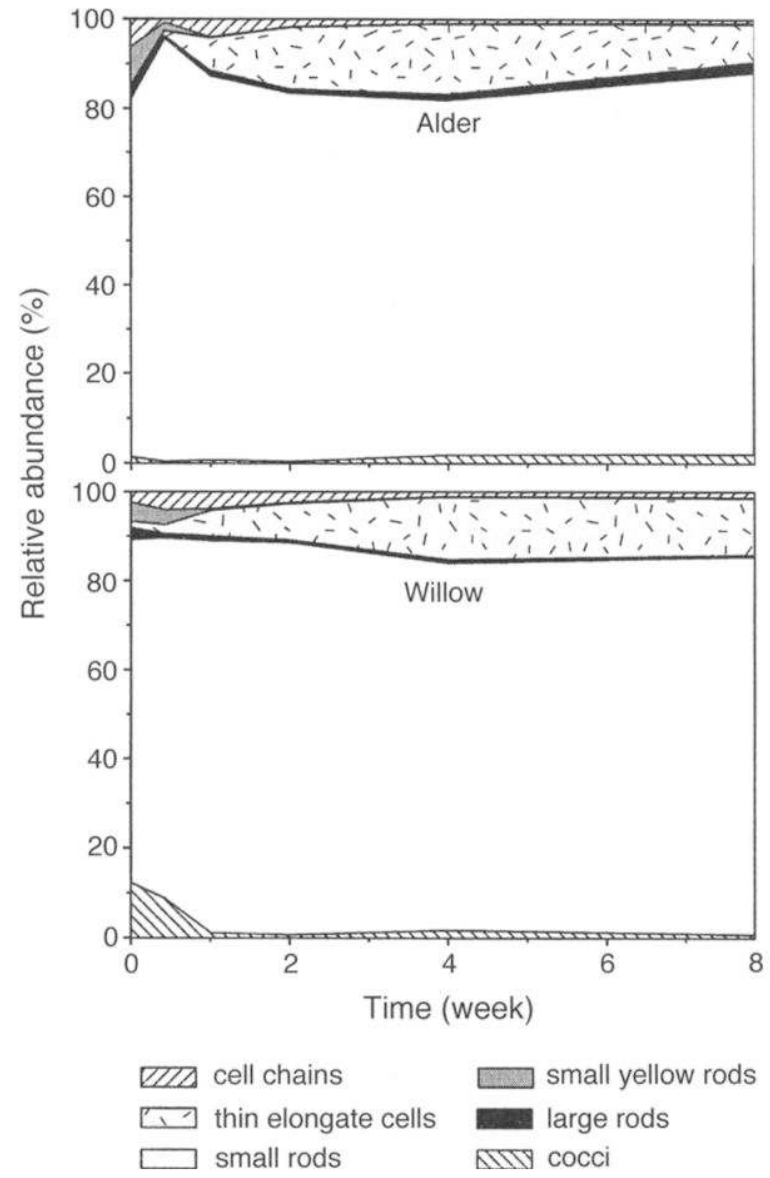

FIG. 5. Changes in the relative proportions of bacterial morphotypes associated with alder and willow leaves decomposing in a third-order reach of a Black Forest stream.

the range above is assumed (i.e., 10\% of the animal body mass consumed per day), the calculated contribution of shredders decreases to $57 \%$. This is a more plausible value, which is similar to the ones obtained in the present study (Table 5) and also to the estimate made by the authors themselves (45\%) using a completely different approach. Thus, even if the average consumption of shredders were half the rate assumed here (cf. Webster 1983), or less, small-sized shredders would be responsible for a major portion of the total mass loss observed in both the present study and at least one further case. Table 6 also illustrates, however, that the importance of shredders to leaf breakdown can be highly variable even among streams accommodating invertebrate assemblages of similar composition. A large part of this variation appears to be driven by differences in animal biomass, rather than by our assumptions about feeding rates.

The fungal component in the present study is estimated to account for a considerably smaller fraction of overall mass loss. Conidial production plus the mycelial biomass accumulated in leaf packs during the first $4 \mathrm{wk}$ of the experiment (i.e., an estimate of the

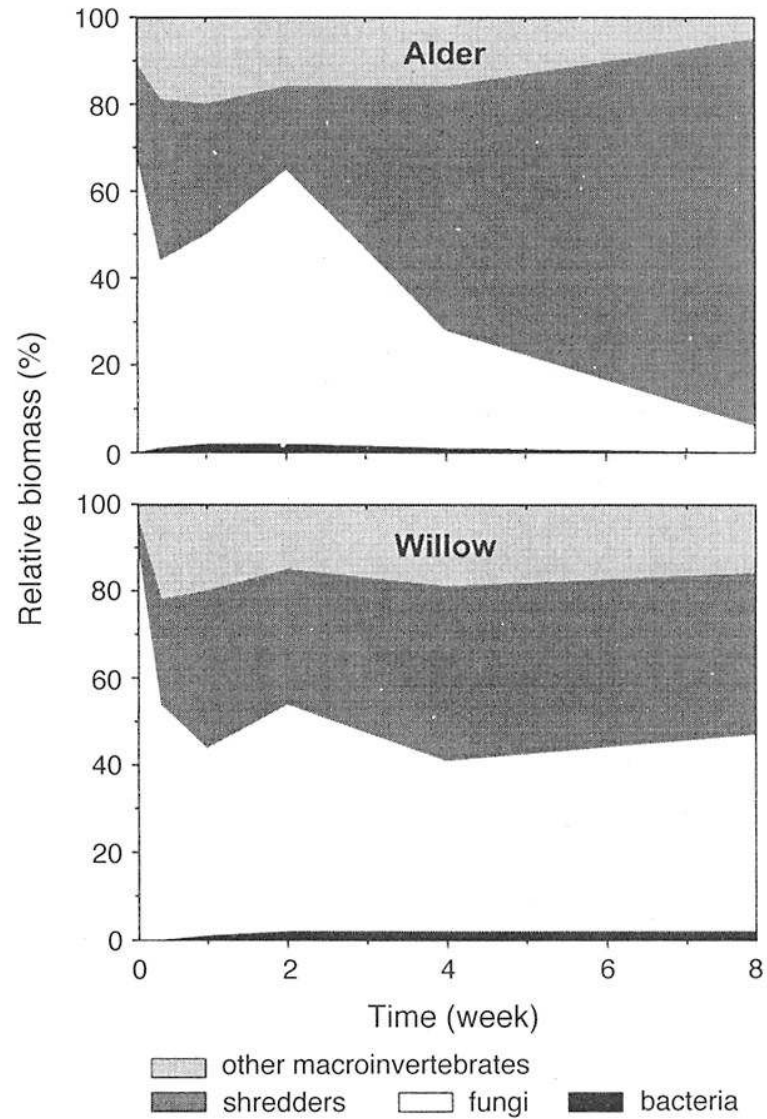

FIG. 6. Changes in the relative biomass proportions of bacteria, fungi, shredders, and other macroinvertebrates associated with alder and willow leaves decomposing in a thirdorder reach of a Black Forest stream.

product of $\mu_{\mathrm{f}}$ and $B_{\mathrm{f}}$ in Eq. 3) account for $18 \%$ of the mass loss in both leaf species, if a growth efficiency $\left(\varepsilon_{\mathrm{f}}\right)$ of $35 \%$ (Suberkropp 1991) is assumed. The corresponding values after $8 \mathrm{wk}$ are $12 \%$ for alder and $13 \%$ for willow. These estimates are conservative, because part of the mycelial biomass is lost through preferential feeding of shredders on leaf patches colonized by fungi (Suberkropp 1992b, 1998) and possibly other mechanisms. There is evidence, moreover, that mycelial growth is sustained in advanced stages of breakdown, despite a net decline in biomass. If a growth rate $\left(\mu_{r}\right)$ of 0.02 per day is assumed during this period (Suberkropp 1995, 2000, Weyers and Suberkropp 1996,

TABLE 5. Estimated contribution of shredders, fungi, and bacteria (\%) to alder and willow leaf mass loss in the Steina. See Methods and Discussion for rationale and specific assumptions underlying calculations.

\begin{tabular}{lcc}
\hline \hline Decomposer & Alder & Willow \\
\hline Shredders & 63.5 & 51.2 \\
Fungi & 14.5 & 18.1 \\
Bacteria & 12.7 & 8.7 \\
Total & 90.7 & 78.0 \\
\hline
\end{tabular}


TABLE 6. Estimates illustrating the range of variation in the percentage contribution of shredders and fungi to leaf litter breakdown.

\begin{tabular}{lllrrrr}
\hline \hline \multicolumn{1}{c}{ Stream } & \multicolumn{1}{c}{ Location } & \multicolumn{1}{c}{ Leaf species } & $\begin{array}{c}\text { Duration } \\
\text { (d) }\end{array}$ & $\begin{array}{c}\text { Shredder } \\
(\%)\end{array}$ & $\begin{array}{c}\text { Fungi } \\
(\%)\end{array}$ & Footnotes \\
\hline Monument Creek & Alaska & S. alaxensis, & 98 & 35 & 8 & $\dagger$ \\
& & S. arbusculoides & & & & \\
Twin Creek & Rocky Mountains, Alberta & S. drummondiana & 223 & 227 & n.d. & $\ddagger$ \\
Little Beaver Creek & Rocky Mountains, Colorado & S. bebbiana & 112 & 8 & n.d. & $\S$ \\
Little Beaver Creek & Rocky Mountains, Colorado & A. tenuifolia & 112 & 8 & n.d. & $\S$ \\
Touyre & Pyreness, France & A. glutinosa & 56 & 26 & 22 & $\|$ \\
Touyre & Pyrenees, France & A. glutinosa & 56 & n.d. & 35 & $\mathbb{I}$ \\
Salderrey stream & Bask Country, Spain & A. glutinosa & 56 & n.d. & 10 & $\#$ \\
\hline
\end{tabular}

Notes: Values were calculated from literature data based on Eq. 4 (see footnotes for more detail). Streams are softwater and accommodate similar shredder assemblages as found in the present study. The abbreviation n.d. $=$ not determined.

$\dagger$ Calculated from mass loss data and shredder biomass in Cowan et al. (1983) and hyphal lengths reported in Buttimore et al. (1984), assuming a hyphal diameter of $3 \mu \mathrm{m}$ and a hyphal dry mass density of $500 \mathrm{fg} / \mu \mathrm{m}^{3}$ (Newell 1992, Gessner 1997). Fungal contribution is underestimated because of (1) limitations of the hyphal-length method used in this study (Newell 1992), (2) the neglect of conidial production, and (3) the unrealistic assumption that fungal production ceased after day 22 , when the maximum fungal biomass per litter bag was attained.

‡ Calculated from leaf mass loss and shredder biomass data in Mutch and Davies (1984); the impossibly high estimate is conceivably due to the extreme shredder biomass together with an overestimate of feeding rates at the freezing temperatures prevailing during the study.

$\S$ Calculated from leaf mass loss and shredder biomass data in Short et al. (1980); there were excessive leaching losses $(28-46 \%)$ within the first $72 \mathrm{~h}$.

|| Calculated from leaf mass loss data in Gessner (1991), shredder biomass data in Gessner and Dobson (1993), and ergosterol concentrations reported in Gessner et al. (1993); the experiment was carried out in 1988. Fungal contribution is underestimated due to (1) the neglect of conidial production and (2) the unrealistic assumption that fungal production ceased after day 14 , when maximum fungal biomass per litter bag was attained.

II Calculated based on unpublished mass loss data, ergosterol concentrations, and fungal sporulation rates reported in Suberkropp et al. (1993), spore masses published by Chauvet and Suberkropp (1998) or, in some cases, calculated and compiled by Gessner and Chauvet (1994), and assumed growth rate (or production:biomass ratio) of $0.02 \mathrm{~d}^{-1}$ for the 4-wk period after the maximum fungal biomass was reached on day 28 (i.e., same assumptions as made for calculating the fungal values shown in Table 5); the experiment was carried out in 1990 (estimate more complete than in 1988; identical methods and similar decay rates in both experiments).

\# Calculated based on leaf mass loss data in Pozo et al. (1998), ergosterol concentrations and fungal sporulation rates reported in Chauvet et al. (1997), spore masses published by Chauvet and Suberkropp (1998), and an assumed growth rate (or production:biomass ratio) of $0.02 \mathrm{~d}^{-1}$ during the 6-wk period after the maximum fungal biomass was reached on day 56 (i.e., same assumptions as made for calculating the fungal values shown in Table 5).

Gessner and Chauvet 1997), the contribution of fungi to leaf breakdown increases to $15 \%$ and $18 \%$, respectively (Table 5). This fraction is sizable, and data from a similar stream studied with identical methods suggest that the potential of fungi may be even higher (Table 6 ), as is indicated also by results from a much larger hardwater stream (Baldy et al. 1995). Other estimates compiled in Table 6 are smaller, however, and although some of the low values are partly due to limitations in methodology (e.g., Buttimore et al. 1984), others (Chauvet et al. 1997, Pozo et al. 1998) appear to reflect a true difference in fungal involvement in the breakdown process among systems. This variation may be related to the abundance of shredders, which act as both competitors and predators of fungi (Bärlocher 1979), but this remains an untested hypothesis.

Based on a bacterial growth efficiency $\left(\varepsilon_{\mathrm{b}}\right)$ of $30 \%$ (del Giorgio and Cole 1998), the calculated bacterial contribution to leaf breakdown in the present study is exceedingly small (1.9\% for alder, $1.8 \%$ for willow), if it is determined in the same manner as for the fungi in the first $4 \mathrm{wk}$ of our experiment. However, Findlay and Arsuffi (1989) and Baldy and Gessner (1997) provide evidence that rapid growth of bacterial cells on decomposing leaves may be offset by concurrent loss- es, resulting in production:biomass ratios ranging from 0.25 to 9 per day. The lowest ratio of $0.25 \mathrm{~d}^{-1}$ would translate into an estimate of bacterial contribution almost exactly the same $(\sim 2 \%)$ as the one derived directly from the measured biomass values; it is probably unrealistically low. Conversely, an assumed average growth rate (or production:biomass ratio) of 1 translates into an estimated bacterial contribution to leaf mass loss of $12.7 \%$ (alder) and $8.7 \%$ (willow) (Table 5). Contributions of this magnitude indicate that bacteria may nearly balance the proportion of total leaf mass loss that is not accounted for by shredders and fungi. It is possible, however, that part of the carbon sustaining bacterial growth is derived from sources outside the leaf compartment, i.e., by DOM in the stream water flowing across leaf surfaces. If this material is used to any significant extent, the contribution of bacteria will be overestimated by the approach adopted here. In fungi, the same phenomenon could theoretically occur, but it is less likely to be important because fungal mycelium penetrates the leaf tissue, rather than growing on its surfaces, suggesting that contact with the surrounding environment is more restricted.

In conclusion, the sum of our independent estimates of organismal contributions to leaf breakdown yields 
plausible results. This is particularly true if one considers that both DOM (Meyer and O'Hop 1983, Baldy and Gessner 1997) and FPOM (Malmqvist 1993, Ward et al. 1994, Wallace and Webster 1996) are generated during leaf breakdown in streams, possibly accounting for the remaining $10-20 \%$ of leaf mass loss (Table 5). A large part of this FPOM is derived from the feces of shredders and is hence included in our estimate as ingested material. However, some FPOM release is due to fungal activity (Suberkropp and Klug 1980), mechanical fragmentation and abrasion, and is unaccounted for in our budget. Thus, despite some uncertainties and simplifications in the assumptions underlying our model (e.g., neglect of interactions among decomposers; Suberkropp 1992b), the results of this study suggest that all types of decomposers (i.e., shredders, fungi, and bacteria) made an appreciable contribution to the leaf litter breakdown process in our study stream. The role of shredders appeared to be particularly important, but literature data suggest this is not invariably the case. Future determinations of leaf-associated microbial production, concomitant with estimates of shredder feeding, will facilitate exploration of the extent of variation and particularly of the causes that lead to shifts in decomposer dominance in different environmental situations.

\section{ACKNOWLEDGMENTS}

We thank Daniel Steiner, Doris Hohmann, Erwin Grieder, and Antonin Mares for invaluable field and laboratory assistance; Johann Waringer, University of Vienna, for verification of caddisfly identifications; Chris Klausmeier for discussion and advice on theoretical issues; Frau Homann at the Regional Water Authority Waldshut-Tiengen, Germany, for providing discharge data; and two anonymous reviewers for their helpful comments on the manuscript.

\section{Literature Cited}

Anderson, N. H., and J. R. Sedell. 1979. Detritus processing by macroinvertebrates in stream ecosystems. Annual Review of Entomology 24:351-377.

Arsuffi, T. L., and K. Suberkropp. 1989. Selective feeding by shredders on leaf-colonizing stream fungi: comparison of macroinvertebrate taxa. Oecologia 79:30-37.

Baldy, V., and M. O. Gessner. 1997. Towards a budget of leaf litter decomposition in a first-order woodland stream. Comptes Rendus de l'Académie des Sciences Série III 320: 747-758.

Baldy, V., M. O. Gessner, and E. Chauvet. 1995. Bacteria, fungi and the breakdown of leaf litter in a large river. Oikos 74:93-102.

Bärlocher, F. 1979. On trophic interactions between microorganisms and animals. American Naturalist 113:147-148.

Bärlocher, F. 1992. The ecology of aquatic hyphomycetes. Springer-Verlag, Berlin, Germany.

Bärlocher, F. 1997. Pitfalls of traditional techniques when studying decomposition of vascular plant remains in aquatic habitats. Limnetica 13:1-11.

Bärlocher, F., and M. Schweizer. 1983. Effects of leaf size and decay rate on colonization by aquatic hyphomycetes. Oikos 41:205-210.

Benke, A. C., A. D. Huryn, L. A. Smock, and J. B. Wallace. 1999. Length-mass relationships for freshwater macroinvertebrates in North America with particular reference to the southeastern United States. Journal of the North American Benthological Society 18:308-343.

Bird, G. A., and N. K. Kaushik. 1985. Processing of elm and maple leaf discs by collectors and shredders in laboratory feeding studies. Hydrobiologia 126:109-120.

Boulton, A. J., and P. I. Boon. 1991. A review of methodology used to measure leaf litter decomposition in lotic environments: time to turn over an old leaf? Australian Journal of Marine and Freshwater Research 42:1-43.

Bratbak, G. 1993. Microscope methods for measuring bacterial biovolume: epifluorescence microscopy, scanning electron microscopy, and transmission electron microscopy. Pages 309-317 in P. F. Kemp, B. F. Sherr, E. B. Sherr, and J. J. Cole, editors. Handbook of methods in aquatic microbial ecology. Lewis Publishers, Boca Raton, Florida, USA.

Burgherr, P., and E. I. Meyer. 1997. Regression analysis of linear body dimensions vs. dry mass in stream macroinvertebrates. Archiv für Hydrobiologie 139:101-112.

Buttimore, C. A., P. W. Flanagan, C. A. Cowan, and M. W. Oswood. 1984. Microbial activity during leaf decomposition in an Alaskan subarctic stream. Holarctic Ecology 7:104-110.

Cadisch, G., and K. E. Giller, editors. 1997. Driven by nature. Plant litter quality and decomposition. CAB International, Wallingford, UK.

Cardinale, B. J., K. Nelson, and M. A. Palmer. 2000. Linking species diversity to the functioning of ecosystems: on the importance of environmental context. Oikos 91:175-183.

Casas, J. J., and M. O. Gessner. 1999. Leaf litter breakdown in a Mediterranean stream characterised by travertine precipitation. Freshwater Biology 41:781-793.

Chauvet, E., E. Fabre, A. Elósegui, and J. Pozo. 1997. The impact of eucalypt on the leaf-associated aquatic hyphomycetes in Spanish streams. Canadian Journal of Botany 75:880-887.

Chauvet, E., and K. Suberkropp. 1998. Temperature and sporulation of aquatic hyphomycetes. Applied and Environmental Microbiology 64:1522-1525.

Cowan, C. A., M. W. Oswood, C. A. Buttimore, and P. W. Flanagan. 1983. Processing and macroinvertebrate colonization of detritus in an Alaskan subarctic stream. Holarctic Ecology 6:340-348.

Cuffney, T. F., J. B. Wallace, and G. J. Lugthart. 1990. Experimental evidence quantifying the role of benthic invertebrates in organic matter dynamics of headwater streams. Freshwater Biology 23:281-299.

del Giorgio, P. A., and J. J. Cole. 1998. Bacterial growth efficiency in natural aquatic systems. Annual Review of Ecology and Systematics 29:503-541.

Emmerson, M. C., M. Solan, C. Emes, D. M. Paterson, and D. Raffaelli. 2001. Consistent patterns and the idiosyncratic effects of biodiversity in marine ecosystems. Nature 411:73-77.

Fagerbakke, K. M., M. Heldal, and S. Norland. 1996. Content of carbon, nitrogen, oxygen, sulfur and phosphorus in native aquatic and cultured bacteria. Aquatic Microbial Ecology 10:15-27.

Findlay, S. E. G., and T. L. Arsuffi. 1989. Microbial growth and detritus transformations during decomposition of leaf litter in a stream. Freshwater Biology 21:261-270.

Fry, J. C. 1990. Direct methods and biomass estimation. Methods in Microbiology 22:41-85.

Galas, J., T. Bednarz, E. Dumnicka, A. Starzecka, and K. Wojtan. 1996. Litter decomposition in a mountain cave stream. Archiv für Hydrobiologie 138:199-211.

Gessner, M. O. 1991. Differences in processing dynamics of fresh and dried leaf litter in a stream ecosystem. Freshwater Biology 26:387-398.

Gessner, M. O. 1997. Fungal biomass, production and spor- 
ulation associated with particulate organic matter in streams. Limnetica 13:33-44.

Gessner, M. O., and E. Chauvet. 1993. Ergosterol-to-biomass conversion factors for aquatic hyphomycetes. Applied and Environmental Microbiology 59:502-507.

Gessner, M. O., and E. Chauvet. 1994. Importance of stream microfungi in controlling breakdown rates of leaf litter. Ecology 75:1807-1817.

Gessner, M. O., and E. Chauvet. 1997. Growth and production of aquatic hyphomycetes in decomposing leaf litter. Limnology and Oceanography 42:496-505.

Gessner, M. O., E. Chauvet, and M. Dobson. 1999. A perspective on leaf litter breakdown in streams. Oikos 85:377384.

Gessner, M. O., and M. Dobson. 1993. Colonisation of fresh and dried leaf litter by lotic macroinvertebrates. Archiv für Hydrobiologie 127:141-149.

Gessner, M. O., E. Meyer, and J. Schwoerbel. 1991. Rapid processing of fresh leaf litter in an upland stream. Verhandlungen der Internationalen Vereinigung für Limnologie 24: $1846-1850$.

Gessner, M. O., and S. Y. Newell. 2002. Biomass, growth rate, and production of filamentous fungi in plant litter. Pages 390-408 in C. J. Hurst, R. L. Crawford, G. R. Knudsen, M. J. McInerney, and L. D. Stetzenbach, editors. Manual of environmental microbiology. Second edition. American Society for Microbiology Press, Washington, D.C., USA.

Gessner, M. O., C. T. Robinson, and J. V. Ward. 1998. Leaf breakdown in streams of an alpine glacial floodplain: dynamics of fungi and nutrients. Journal of the North American Benthological Society 17:403-419.

Gessner, M. O., and A. L. Schmitt. 1996. Use of solid-phase extraction to determine ergosterol concentrations in plant tissue colonized by fungi. Applied and Environmental Microbiology 62:415-419.

Gessner, M. O., K. Suberkropp, and E. Chauvet. 1997. Decomposition of plant litter by fungi in marine and freshwater ecosystems. Pages 303-322 in D. T. Wicklow and B. E. Söderström, editors. The Mycota. Volume 4: environmental and microbial relationships. Springer-Verlag, Berlin, Germany.

Gessner, M. O., M. Thomas, A.-M. Jean-Louis, and E. Chauvet. 1993. Stable successional patterns of aquatic hyphomycetes on leaves decaying in a summer cool stream. Mycological Research 97:163-172.

Grafius, E., and N. H. Anderson. 1979. Population dynamics, bioenergetics, and role of Lepidostoma quercina (Trichoptera, Lepidostomatidae) in an Oregon, USA, woodland stream. Ecology 60:433-441.

Hector, A., A. J. Beale, A. Minns, S. J. Otway, and H. J. Lawton. 2000. Consequences of the reduction of plant diversity for litter decomposition: effects through litter quality and microenvironment. Oikos 90:357-371.

Herbst, G. 1982. Effects of leaf type on the consumption rates of aquatic detritivores. Hydrobiologia 89:77-87.

Howe, M. J., and K. Suberkropp. 1994. Effects of isopod (Lirceus sp.) feeding on aquatic hyphomycetes colonizing leaves in a stream. Archiv für Hydrobiologie 130:93-103.

Hutchens, J. J., Jr., E. F. Benfield, and J. R. Webster. 1997. Diet and growth of a leaf-shredding caddisfly in southern Appalachian streams of contrasting disturbance history. Hydrobiologia 346: 193-201.

Jones, C. G., and J. H. Lawton, editors. 1995. Linking species and ecosystems. Chapman and Hall, New York, New York, USA.

Jonsson, M., and B. Malmqvist. 2000. Ecosystem process rate increases with animal species richness: evidence from leaf-eating, aquatic insects. Oikos 89:519-523.

Kaushik, N. K., and H. B. N. Hynes. 1971. The fate of the dead leaves that fall into streams. Archiv für Hydrobiologie 68:465-515.

Kirchman, D. L. 1993. Statistical analysis of direct counts of microbial abundance. Pages 117-119 in P. F. Kemp, B. F. Sherr, E. B. Sherr, and J. J. Cole, editors. Handbook of methods in aquatic microbial ecology. Lewis Publishers, Boca Raton, Florida, USA.

Loferer-Krößbacher, M., J. Klima, and R. Psenner. 1998. Determination of bacterial cell dry mass by transmission electron microscopy and densitometric image analysis. Applied and Environmental Microbiology 64:688-694.

Maamri, A., E. Pattee, X. Gayte, and H. Chergui. 1999. Microbial dynamics on decaying leaves in a temporary Moroccon river. II. Bacteria. Archiv für Hydrobiologie 144: $157-175$.

Malmqvist, B. 1993. Interactions in stream leaf packs: effects of a stonefly predator on detritivores and organic matter processing. Oikos 66:454-462.

Malmqvist, B., and D. Oberle. 1995. Macroinvertebrate effects on leaf pack decomposition in a lake outlet stream in Northern Sweden. Nordic Journal of Freshwater Research 70:12-20.

Maltby, L. 1992. Detritus processing. Pages 331-353 in P. Calow, editor. The rivers handbook. Volume 1. Hydrological and ecological principles. Blackwell Scientific Publications, Oxford, UK.

McArthur, J. V., J. M. Aho, R. B. Rader, and G. L. Mills. 1994. Interspecific leaf interactions during decomposition in aquatic and floodplain ecosystems. Journal of the North American Benthological Society 13:57-67.

McArthur, J. V., and J. R. Barnes. 1988. Community dynamics of leaf litter breakdown in a Utah alpine stream. Journal of the North American Benthological Society 7:37-43.

Merritt, R. W., and K. W. Cummins. 1996. An introduction to the aquatic insects of North America. Third edition. Kendall-Hunt, Dubuque, Iowa, USA.

Meyer, E. 1989. The relationship between body length parameters and dry mass in running water invertebrates. Archiv für Hydrobiologie 117:191-203.

Meyer, E., J. Schwoerbel, and G. C. Tillmanns. 1990. Physikalische, chemische und hydrographische Untersuchungen eines Mittelgebirgsbaches: Ein Beitrag zur Typisierung kleiner Fließgewässer. Aquatic Sciences 52:236-255.

Meyer, J. L., and J. O'Hop. 1983. Leaf-shredding insects as a source of dissolved organic carbon in headwater streams. American Midland Naturalist 109:175-183.

Moog, O. 1995. Ernährungstypen. Part III, 89 pages in O. Moog, editor. Fauna Aquatica Austriaca. Wasserwirtschaftskataster, Bundesministerium für Land- und Forstwirtschaft, Vienna, Austria.

Mutch, R. A., and R. W. Davies. 1984. Processing of willow leaves in two Alberta Rocky Mountain streams. Holarctic Ecology 7:171-176.

Newell, S. Y. 1992. Estimating fungal biomass and productivity in decomposing litter. Pages 521-561 in G. C. Carroll and D. T. Wicklow, editors. The fungal community: its organization and role in the ecosystem. Second edition. Marcel Dekker, New York, New York, USA.

Nolen, J. A., and R. G. Pearson. 1993. Factors affecting litter processing by Anisocentropus kirramus (Trichoptera: Calamoceratidae) from an Australian tropical rainforest stream. Freshwater Biology 29:469-479.

Oremland, R. S., and D. G. Capone. 1988. Use of 'specific' inhibitors in biogeochemistry and microbial ecology. Pages 285-383 in K. C. Marshall, editor. Advances in microbial ecology. Volume 10. Plenum, New York, New York, USA.

Otto, C. 1974. Growth and energetics in a larval population of Potamophylax cingulatus (Steph.) (Trichoptera) in a South Swedish stream. Journal of Animal Ecology 43:339361 . 
Padgett, D. E. 1976. Leaf decomposition by fungi in a tropical rainforest stream. Biotropica 8:166-178.

Padgett, D. E. 1993. Distinguishing bacterial from nonbacterial decomposition of Spartina alternifora by respirometry. Pages 465-469 in P. F. Kemp, B. F. Sherr, E. B. Sherr, and J. J. Cole, editors. Handbook of methods in aquatic microbial ecology. Lewis Publishers, Boca Raton, Florida, USA.

Pelegrí, S. P., J. Dolan, and F. Rassoulzadegan. 1999. Use of high temperature catalytic oxidation (HTCO) to measure carbon content of microorganisms. Aquatic Microbial Ecology 16:273-280.

Petersen, R. C., and K. W. Cummins. 1974. Leaf processing in a woodland stream. Freshwater Biology 4:343-368.

Pozo, J., A. Basaguren, A. Elósegui, J. Molinero, E. Fabre, and E. Chauvet. 1998. Afforestation with Eucalyptus globulus and leaf litter decomposition in streams of northern Spain. Hydrobiologia 373/374:101-109.

Short, R. A., S. P. Canton, and J. V. Ward. 1980. Detrital processing and associated macroinvertebrates in a Colorado mountain stream. Ecology 61:727-732.

Short, R. A., and J. V. Ward. 1981. Trophic ecology of three winter stoneflies (Plecoptera). American Midland Naturalist 105:341-347.

Simon, M., and F. Azam. 1989. Protein content and protein synthesis rate of planktonic marine bacteria. Marine Ecology Progress Series 51:201-213.

Suberkropp, K. 1991. Relationships between growth and sporulation of aquatic hyphomycetes on decomposing leaf litter. Mycological Research 95:843-850.

Suberkropp, K. 1992a. Aquatic hyphomycete communities. Pages 729-747 in G. C. Carroll and D. T. Wicklow, editors. The fungal community. Its organization and role in the ecosystem. Second edition. Marcel Dekker, New York, New York, USA.

Suberkropp, K. 1992b. Interactions with invertebrates. Pages 118-133 in F. Bärlocher, editor. The ecology of aquatic hyphomycetes. Ecological Studies. Volume 94. SpringerVerlag, Berlin, Germany.

Suberkropp, K. 1995. The influence of nutrients on fungal growth, productivity, and sporulation during leaf breakdown in streams. Canadian Journal of Botany (Supplement) 73:S1361-S1369.

Suberkropp, K. F. 1998. Microorganisms and organic matter decomposition. Pages $120-143$ in R. J. Naiman and R. E. Bilby, editors. River ecology and management: lessons from the Pacific Coastal Ecoregion. Springer-Verlag, New York, New York, USA.

Suberkropp, K. 2000. Estimating production of litter-decomposing fungi in streams from rates of acetate incorporation into ergosterol. Verhandlungen der Internationalen Vereinigung für Theoretische und Angewandte Limnologie 27: 2426-2429.
Suberkropp, K., M. O. Gessner, and E. Chauvet. 1993. Comparison of ATP and ergosterol as indicators of fungal biomass associated with decomposing leaves in streams. Applied and Environmental Microbiology 59:3367-3372.

Suberkropp, K., and M. J. Klug. 1980. The maceration of deciduous leaf litter by aquatic hyphomycetes. Canadian Journal of Botany 58:1025-1031.

SYSTAT. 1998. SYSTAT 8.0 for Windows. SPSS, Chicago. Illinois, USA.

Theil-Nielsen, J., and M. Søndergaard. 1998. Bacterial carbon biomass calculated from biovolumes. Archiv für $\mathrm{Hy}-$ drobiologie 141: 195-207.

Tilman, D. 1999. The ecological consequences of changes in biodiversity: a search for general principles. Ecology 80: 1455-1474.

Wagener, S. M., M. W. Oswood, and J. P. Schimel. 1998. Rivers and soils: parallels in carbon and nutrient processing. BioScience 48:104-108.

Wallace, J. B., S. L. Eggert, J. L. Meyer, and J. R. Webster. 1997. Multiple trophic levels of a forest stream linked to terrestrial litter inputs. Science 277:102-104.

Wallace, J. B., and J. R. Webster. 1996. The role of macroinvertebrates in stream ecosystem function. Annual Review of Entomology 41:115-139.

Ward, G. M., A. K. Ward, C. N. Dahm, and N. G. Aumen. 1994. Origin and formation of organic and inorganic particles in aquatic systems. Pages 45-73 in R. S. Wotton, editor. The biology of particles in aquatic systems. Second edition. Lewis Publishers, Boca Raton, Florida, USA.

Webster, J. R. 1983. The role of benthic macroinvertebrates in detritus dynamics of streams: a computer simulation. Ecological Monographs 53:383-404.

Webster, J. R., and E. F. Benfield. 1986. Vascular plant breakdown in freshwater ecosystems. Annual Review of Ecology and Systematics 17:567-594.

Webster, J. R., E. F. Benfield, T. P. Ehrman, M. A. Schaeffer, J. L. Tank, J. J. Hutchens, and D. J. D'Angelo. 1999. What happens to allochthonous material that falls into streams? A synthesis of new and published information from Coweeta. Freshwater Biology 41:687-705.

Webster, J. R., and J. L. Meyer, editors. 1997. Stream organic matter budgets. Journal of the North American Benthological Society 16:3-161.

Webster, J. R., J. B. Wallace, and E. F. Benfield. 1995. Organic processes in streams of the eastern United States. Pages 117-187 in C. E. Cushing, K. W. Cummins, and G. W. Minshall, editors. Ecosystems of the world. Volume 22. River and stream ecosystems, Elsevier, Amsterdam, The Netherlands.

Weyers, H. S., and K. Suberkropp. 1996. Fungal and bacterial production during the breakdown of yellow poplar leaves in 2 streams. Journal of the North American Benthological Society 15:408-420. 